\title{
Make Moral Judgment of Political Figures in the Election of The Governor of West Java
}

\author{
Olih Solihin \\ Communication Studies Program \\ Universitas Komputer Indonesia \\ Bandung, Indonesia \\ Email: olih.solihin@email.unikom.ac.id
}

\begin{abstract}
This study aims to find out how to make Moral Judgment on political figures in the election of the Governor and Deputy Governor of West Java by the Radar Bandung newspaper. Radar Bandung has a positive assessment of the candidate pair Deddy Mizwar and Dedi Mulyadi as candidates for Governor and Deputy Governor of West Java for the period 2018-2013. This research uses a qualitative method with Robert $\mathbf{N}$. Entemen's framing analysis model approach. To get the answer to this framing, the researcher focuses on the moral assessment section only. The results showed that the moral assessment that was wanted to be conveyed by the Radar Bandung newspaper, to one of the candidates, Deddy Mizwar and Dedi Mulyadi, was very positive in evaluating the other candidates. The Conclusion research is Radar Bandung newspaper gives a very good moral decision to political figure Deddy Mizwar-Dedi Mulyadi. Suggestion: Koran Radar Bandung tries its best to explore the good and bad sides of all candidates so that the assessment is more comprehensive.
\end{abstract}

Key word: framing, figure politic, mass media, Candidate Governor and Deputy Governor

\section{INTRODUCTION}

West Java political figures advanced in the event for the election of West Java governor and vice governor candidates for the period 2018-2023. Candidates for Governor and Deputy Governor of West Java period 2018-2023, respectively number 1 Ridwan Kamil- Uu Ruzhanul Ulum, Number two Tb. Hasanuddin - Anton Charliyan, Number three SudrajatAhmad Shaikhu, and number four Deddy Mizwar-Dedi Mulyadi. Of the four candidates, Radar Bandung edition 15 March 2018 reported on the first page that the pair number one Deddy Mizwar-Dedi Mulyadi excelled. In its report, the Jawa Pos group newspaper said electability Deddy Mizwar-Dedi Mulyadi was at the top of the results of the latest electability survey in West Java Pilgub. Even so, the pair carried by the Golkar and Democratic Party chose not to dissolve in euphoria and remain focused on socializing the program to the public.

The superiorityf of the candidates was based on the Kompas Research and Development survey published on Wednesday (3/14), the electability of the number 4 pair reached 42.8 percent of the votes. Followed by the Rindu couple or Ridwan Kamil-Uu Ruzhanul who received 39.9 percent. Meanwhile, the Sudrajat-Ahmad Syaikhu pair (Fun) was scattered in third place with 7.8 percent and TB partner Hasanuddin-Anton Charliyan (Hasanah) was only able to reach 3.1 percent.

The construction of the news coverage of the Radar Bandung newspaper influences the attitudes and views of the people of West Java in determining their political choices. As understood together that a mass media report will get interpretation from the community.

Framing analysis can simply be described as an analysis to find out how reality (events, actors, groups, or whatever) is framed by the media. The framing is of course through the construction process, how reality is constructed by the media, by the way and technique what the event is emphasized and highlighted, whether in the news there are parts that are omitted or even hidden.

According to the news constructionist view is the result of social construction which always involves the views, ideologies and values of journalists or the media. Journalists like actors who form reality. Journalists are not just scavengers who take facts, because in reality there is no real reality [1]

Journalists are the ones who form events, which are called news and which are not. Events and reality are not selected but created by journalists, in the sense of how the reporter made the news.

Media and journalists present the event so that the community can understand it. Because reality and events are very complex and random, so they must be identified, linked to events that are known by the 
community and placed in a particular social context, where the community is located so that random events are organized and meaningful / relevant to the community.

The framing ultimately determines how reality is present in front of readers. What we know about social reality basically depends on how we frame the event which gives a certain understanding and meaning to an event. Looking at the description above, it can be concluded that the formulation of the problem is divided into two, namely the formulation of a macro problem and the formulation of a micro problem. Then the problem can be formulated as follows: "How to Make Moral Judgment of political figures in the election of the Governor of West Java"

This study uses content analysis research. Where researchers use the theory to explain the content of news framing analysis of $\mathrm{N}$. Robert Entman and analyze data based on the Define problems (problem definition), Diagnose causes (estimate problem or source of the problem), Make moral judgment (moral decision making), and treatment recommendation (emphasizing completion). After analyzing existing news it can be seen that the news about Sinyo Harry Sarundayang's participation in the presidential conventions Daily Komentar and Tribun Manado and presented differently. News framing is done both print media is different because the purpose of reporting each print is different. Through the analysis of news framing presidential convention we knows that the mass media, especially newspapers to announce something in a balanced way, adhere to the Code of Ethics of Journalism in conveying information to the public. Do not take sides or cornering object reported. Readers of the print media is also not only receive information only from the media, it would be nice if you read more than one medium in order to obtain more complete information.

Wolipop is pages that presenting news or lifestyle articles about women, including the fashion rubric discussing the aspect of fashion from within the country and overseas which becomes a trend to date. As an online media which broadcasts information to the public, wolipop also features images of women which can be a reference to those who read it. This research is qualitative research that uses a method of William A. framing analysis. Gamson and modgliani argued that the frame is the way to talk, which presents construction meaning over events pertaining to an object of a discourse. The technique of collecting data used in this research is: documentary study of the primary data by collecting articles written on the fashion rubric of Wolipop from May 13 to 17, and also may 19, 2013. The news articles observed were selected based on the number of visitors every day. The result shows that wolipop always constructs women as figures who always want to look young, figures who can be influenced, figures of fashion adicts who shop high value goods although the goods are not very important. Lastly, wolipop gives images of women as tough figures who dare to demand their rights, try to seek freedom and refuse to be pre-sighted.

At the level of preparing facts (syntactic), Lampung Post describes the image of the candidate pair and vice mayor of Lampung city for the period 2010-2015 through an open campaign and debate on the vision and mission of each candidate pair of mayor and vice mayor of Bandar Lampung. At the fact-telling level (Script), Lampung Post tries to narrate the facts formed by the $5 \mathrm{~W}+1 \mathrm{H}$ pattern which prioritizes reporting on the imaging aspect of Bandar Lampung's mayor and vice mayor candidate pairs for the period 2010-2015 by looking at their vision and mission in the candidate debate or partner campaign from each candidate. At the level of the (thematic) fact writing Lampung Post put forward many themes about the commitment of each Bandar Lampung mayor and vice mayor candidate pair for the period 2010-2015, where the candidate pairs did not have clear priorities about the vision and mission they conveyed. At the level of fact suppression (Rhetoric), Lampung Post is an authority or position label to support the ideas or opinions of the interviewees. The conclusion that can be drawn from this research is that this event shows how there has been a symbolic war between those who have an interest in this issue. The media has its own discourse strategy in interpreting the reactions generated in the issue of news about the image of Bandar Lampung's mayor and vice mayor's candidate pair for the period 2010-2015, both about the vision mission in the candidate debate and the campaign of each candidate pair.

Framing analysis method by Robert N. Entman model with four devices, namely Define Problems, Diagnose Cause, Make Moral Judgment, and Treatment Recommendation. by emphasizing the prominence of the frame of mind, perspective and concept of interpreting a news. The results of this study indicate that the issue raised by online media, detik.com is a political issue. Then it can be concluded that detik.com displays the reality of the existing news in accordance with the facts or it is not realized that the range of information conveyed can affect the mindset of its readers.

The results of this study showed that the Kaltim Post framing through its news showed that there were still penojolan-penojolan which were still within the limits of fairness towards Awang Faroek Ishak by always giving positive news. This shows that the power of the owners of media companies greatly influences the content of the news. Framing Tribun Kaltim through its reporting in the 2013 East Kalimantan Governor election rubric during the campaign period showed impartiality and was not inclined towards one 
of the 2013 East Kalimantan Governor candidates, seen Tribun Kaltim trying to build the real reality.

\section{METHOD}

This study uses a qualitative method with Robert $\mathrm{N}$ Entman's framing analysis design. Framing is a way of how events are presented by the media. The presentation is done by emphasizing certain parts, highlighting certain aspects and enlarging how to tell certain stories from a reality of events. Here the media selects, connects, and accentuates events so that the meaning of events is more easily touched and remembered by audiences, framing makes the world more known and understood. Complex reality is understood and simplified in certain categories, for audiences, the presentation of such reality makes reality more meaningful and understandable [2].

In addition to highlighting certain parts and aspects to make it easier for audiences to know a reality. Framing is also an approach to knowing how the perspective or perspective used by journalists and editors. Which ultimately determines which facts are taken, which parts are highlighted or omitted, and where to take the news. Framing, as Todd Gitlin said, is a strategy of how reality or the world is formed and simplified in such a way as to be displayed to the audience [3]

\section{RESULT AND DISCUSSION}

The researcher conducted an analysis based on Robert N. Entman on the results of interviews with journalist of Radar Bandung Bahi Binyatillah, Candidate for Governor Candidate-Deputy Governor of West Java "Deddy Mizwar-Dedi Mulyadi Unggul. Framing Robert N. Entman's concept illustrates broadly how events are interpreted and marked by journalists. The same event can be interpreted differently by each mass media. Different meanings and understandings can be labeled, words, sentences, graphs, and certain emphasis in news narratives. News texts that have been selected will be analyzed using Robert N. Entman's framing method, namely make moral judgment (making moral choices to the public). [4]

The selection of the moral assessment that the Radar Bandung newspaper wanted to convey was based on the interview with Bahi, that the number four candidate, Deddy Mizwar and Dedi Mulyadi, were candidates who were superior to other candidates. The reason, the candidate who carried the Golkar Democratic Party was a defense. Deddy Mizwar is a
West Java deputy governor who is non-active, and Dedi Mulyadi is the Purwakarta regent for two periods of inactivity so that both are believed to be very capable in the field of government bureaucracy in the province with the largest population in Indonesia. According to Bahi Dedi Mulyadi is a reliable politician, who is able to make the right narrative according to the situation and conditions. The proof, Dedi Mulyadi was elected as chairman of the Golkar Party of West Java.

Although other candidates also have a defense, the pair number one Ridwan Kamil as Walkota Bandung is non-active and $\mathrm{Uu}$ Ruzhanul Ulum as Regent of Tasikmalaya is inactive, but his level as under Deddy Mizwar remembers this famous artist his position as Deputy Governor. Deddy is believed to have more value than pair number one. Likewise with candidate number three namely the pair Sudrajat-Ahmad Syaikhu, where Shaikhu is the inactive vice regent of Bekasi.

The next moral value, Deddy Mizwar is a religious figure so it is suitable to be paired with Dedi Mulyadi who is known as a Sundanese cultural observer. Deddy who is also a veteran actor in this country has been known to the public as a wise and charismatic figure. The question of Deddy who is religious is not not without evidence, he always prays on time, even if he is on the field, he always invites the clerics to congregate with him.

The more value the couple has is believed to be able to attract sympathy from the West Javanese people who will carry out the voting later. The candidates for Governor and Deputy Governor of West Java are not just anyone, but figures who have the ability to lead. However, the public will look for candidates who have the most value. It can be concluded from making a moral decision that the news of Candidate Governor and Deputy Governor of West Java Deddy MizwarDedi Mulyadi Unggul by the Radar Bandung newspaper emphasized that the community must choose candidates who have many advantages.

News about West Java political figures in the nomination event for the Governor and Deputy Governor of West Java so dominated the mass media, especially those in West Java. Among the political figures, the name of Deddy Mizwar who came from behind the artist was very interesting for the media to continue to raise it in their news. In addition, Deddy Mizwar was the Deputy Governor of the 2013-2018 period who was considered to have a strong influence in the community. Koran Radar Bandung in the March 15, 2018 edition raised the headline "Deddy MizwarDedi Mulyadi Excellent ". Radar Bandung newspaper certainly has a different view from each news published in a certain period of time in which the tendency to fill the text of the news reported. In this study the news that was considered important by the Radar Bandung newspaper in the framing of the news "Deddy Mizwar- 
Dedi Mulyadi Excellent" from Robert N.Entman focused on make moral judgment.

\section{Mass Communication}

Basically mass communication is a process of communication through mass media (print and electronic media). Message spreaders convey information without knowing who the recipient of the message is and which group. Acceptance of mass communication messages is not only in large numbers (heterogeneous). However, the recipient also consists of different people, including age, religion, gender, occupation, social level, and so on.

To limit mass communication and every form of mass communication has its own characteristics. In defining mass communication, experts have differences in providing limits to the meaning of this term. Understanding of mass communication put forward by Severin and Tankard Jr., in his book Communication Theories: Origins, Methods, And Uses In The Mass Media, namely: "Mass communication is a part of skills, some art, and some knowledge. It is a skill in the sense that it includes certain fundamental techniques that can be learned such as focusing a television camera, operating a tape recorder or taking notes when interviewing. It is art in the sense that it encompasses creative challenges such as writing scripts for television programs, developing an aesthetic layout for magazine advertisements or displaying mesmerizing news stories for a news story. It is a science in the sense that it includes certain principles about how communication takes place that can be developed and used to make things better"[5].

The simplest Mass Communication was put forward by Bittner, namely: "Mass communication is mass medium communicated messages in a large number of people (mass communication is a message communicated through mass media to a large number of people)".

According to Effendy (1993), mass communication is communication through modern mass media, such as newspapers, radio, film and television [6]. Through the mass media an information or message can be conveyed to various communicators and a large number simultaneously. Meanwhile, Djalaluddin Rakhmat in his book Psychology of Communication said; "Mass communication is a type of communication aimed at a number of scattered, heterogeneous and anonymous audiences, through print or electronic media so that the same message can be received simultaneously and momentarily". It can be concluded that mass communication is a process of communication that is carried out through mass media and aimed at a dispersed audience with a specific purpose.

\section{Print Media}

Literally, the understanding of print media can be interpreted as a media for delivering information that has and is related to the interests of the people, which is conveyed in writing. From this understanding, we can see that the print media is a media which contains information related to the interests of the general public and not limited to certain groups.

This print media is part of the community information channel in addition to electronic media and digital media. And in the midst of such rapid community dynamics, print media is considered to be lagging behind the two competitors, namely electronic media and digital media. However, this does not mean that the print media is not able to reach consumers who are waiting for the information it carries.

From the understanding of the print media, there are advantages of this media compared to the two competitors. Print media can convey a detailed and detailed information. As for electronic and digital media, they prioritize information speed. So that not infrequently the information conveyed is more piece and repetitive.

Every media has its own interests and ideologies that it wants to convey to the public through its reporting. This is supported by capacity as a source of information that has a major influence in shaping the mindset of the community. At least the contents of the mass media provide a topic of thought for the community.

Media coverage on certain sides and interviews with certain parties not only as part of journalistic techniques, but indicates how events are displayed and interpreted. The focus of framing analysis is how the media understand and interpret reality and in what way the reality is signified and shaped by the media and journalists.

Reference [7] stated that Robert N. Entman sees framing in two big dimensions: selection of issues and emphasis or emphasis on certain aspects of reality / issues. Entman said: "Framing is an approach to knowing how the perspective or perspective used by journalists when selecting issues and writing news. The perspective or perspective ultimately determines what facts are taken, which parts are highlighted and eliminated, and where to take the news).

\section{News paper}

Initially newspapers were often identified with the press. However, because the understanding of the press has become more widespread, where television and radio are now categorized as press as well, there is a sense of the press in the broad and narrow sense. In 
terms of broad press, the press includes all mass media, both print and electronic. Whereas in a narrow sense, the press only covers printed mass media, one of which is a newspaper. According to Kurniawan Junaidi, what is meant by newspapers is: "The name for press publishing that is included in printed mass media is in the form of sheets containing news, articles and advertisements and is published periodically, can be daily, weekly, monthly and circulated in general, the contents must be actual, also must be universal, meaning that the news must be related to humans from various groups and circles " [8].

Newspapers in Indonesia come in various forms whose types depend on the frequency of publication, form, economy class of readers, circulation and emphasis on its contents. While the understanding of newspapers according to Onong Uchjana Effendy is: "Printed sheets containing reports that occur in the community with the characteristics of periodic, general, actual / actual contents, knowing everything in the world that contains values to be known to the public reader "[9].

\section{News}

News is a form of report about an event that is happening recently or a recent description of an event. In other words, news is an interesting fact or something important that is conveyed to the public through the media. But not all facts can be appointed as news by the media. Because every fact will be chosen which is appropriate to be conveyed to the community.

The word "News" itself is derived from Sanskrit, vrit (meaning there is or occurs) or vritta (meaning event or event). While the big Indonesian dictionary says, news is a report about a warm event or event. According to JB. Wahyudi, author of Journalism Communication book, news is a description of facts and or opinions that contain news values and which have been presented through periodic mass media. News sources are facts and data of an event, including what then becomes the news formula, $5 \mathrm{~W}+\mathrm{IH}$ : What (what happens), Where (where it happened), When (when the event happened), Who (who was involved in the incident), Why (why it happened), and How (how it happened).

\section{News Structure}

The composition or structure of the news, especially in direct news, generally refers to the structure of the inverted pyramid, which starts the news writing by presenting the news section that is considered the most important, then followed by parts that are considered rather important, less important, and so on. The news arrangement of this inverted pyramid form benefits the reader in terms of time efficiency because it immediately knows the most important news. Therefore, this form can attract the attention of readers.

\section{Framing Review}

Framing analysis is a tradition in the realm of communication that emphasizes a multidisciplinary approach in analyzing written and oral messages. Basically framing is a method to see how to tell (story telling) media for events. The way to tell the story is reflected in the "way of seeing" the reality that is made into the news[10].

Sudibyo defines framing as a method of presenting reality in which the truth about an event is not totally denied, but is deflected subtly, by highlighting certain aspects only, using terms that have certain connotations, and with the help of photographs, caricatures and other illustration tools [11].

In communication science, the concept of framing is often used to describe the selection process and the prominence of certain aspects of reality by the mass media. Framing can be viewed as the placement of information in a typical context so that certain issues are allocated more than other issues. In other words, framing analysis can be used to find out how perspectives or ways of view are used by journalists or mass media.

Framing analysis can simply be described as an analysis to find out how reality is framed by the media. Reality is interpreted through the construction process. As well as reporting on West Java political figures ahead of the 2018-20123 governor election. Radar Bandung made the title allegedly tendentious in favor of the number four pair Deddy Mizwar-Dedi Mulyadi. Of course the newspaper, in this case the Radar Bandung journalist, constructs the debate into a reality, and how the media selects the issue and also emphasizes aspects of a reality to be interpreted and understood by the public.

According to Robert N. Entman processes the selection of issues and the prominence of aspects of reality carried out by the media can be seen by: Define problems or defining problems, are the main elements in the framing process carried out by the media, Diagnose causes or estimating the causes of problems, these elements is an element that considers who is the actor of an event, what causes or what (who) to understand an event, Make moral judgment or make a moral choice, is an element to explain or argue against an event that has been defined, Treatment judgment or emphasizing completion, is an element used to assess what is desired by journalists, and what ways are used to solve problems [12]. 
Of the four aspects mentioned above, the researcher only focuses on one problem, namely Make moral judgment or make moral choices towards the audience, especially the readers of this newspaper. Based on the concept of Robert N. Entman events or reality are selected by the media and also highlight certain aspects to be interpreted and understood by the public. Even though the event or issue is the same, but in each delivery each media has different ways of highlighting the news that is made, so that even though the news is the same but the content of the news certainly varies from one media to another. In presenting the news about the debate of the Governor Candidate and the Deputy Governor of West Java 2018, Radar Bandung has a moral assessment that is different from other mass media. The difference can be seen from the words used, the preparation of sentences, and the use of graphics or images to support the content of the news delivered.

\section{CONCLUSION}

In reporting West Java political figures ahead of the election of West Java Governor 2018-2013 period, the Radar Bandung newspaper was interested in appointing one of the candidates for Governor and Deputy Governor, Deddy Mizwar-Dedi Mulyadi. The view of the Radar Bandung newspaper to the Governor and Deputy Governor of West Java candidate period 2018-2023 is good.

The basis for a good assessment of candidate number four is in the track record of this pair. Deddy Mizwar as the defense of the Deputy Governor of West Java for the period 2013-2018 who is also a figure of leader who is religious and wise. Dedi Mulyadi, besides the resignation of the Purwakarta Regent, was also a figure of a reliable politician, and the chairman of a political party in West Java.

\section{ACKNOWLEDGEMENT}

The author would like to give appreciation to Universitas Komputer Indonesia, This research was sponsored by Universitas Komputer Indonesia and Community Service Institute.

\section{REFERENCE}

[1] Bungin, Burhan.. Konstruksi Sosial Media Massa. Jakarta: Kencana, 2008
[2] Eriyanto, Analisis Framing: Konstruksi, Ideologi, dan Politik Media. Yogyakarta: LKiS Pelangi Aksara., 2002

[3] Eriyanto, Analisis Framing: Konstruksi, Ideologi, dan Politik Media. Yogyakarta: LKiS Pelangi Aksara., 2002

[4] Entman, Robert M, Framing: Towards Clarification of Fractured Paradigm (Journal of Communication). PP/S, . 1993.

[5] Severin, W.J., dan James W.T,Jr. 2001. Communication Theories: Origins, Methods, and Uses in the Mass Media. Fifth edition. USA: Longman.

[6] Effendy, Onong Uchjana. Ilmu, Teori \& Filsafat Komunikasi. Bandung: PT. Citra Aditya Bakti, 1993

[7] Entman, Robert M, Framing: Towards Clarification of Fractured Paradigm (Journal of Communication). PP/S, . 1993.

[8] Junaidi, Kurniawan. Ensiklopedia Pers Indonesia, Jakata: Gramedia, 1991

[9] Effendy, Onong Uchjana. Ilmu, Teori \& Filsafat Komunikasi. Bandung: PT. Citra Aditya Bakti, 1993

[10] Eriyanto, Analisis Framing: Konstruksi, Ideologi, dan Politik Media. Yogyakarta: LKiS Pelangi Aksara., 2002

[11] Sobur, Alex. Analisis Text Media: Suatu Pengantar untuk Analisis Wacana, Analisis Semiotik dan Analisis Framing. Bandung: Remaja Rosdakarya, 2012

[12] Eriyanto, Analisis Framing: Konstruksi, Ideologi, dan Politik Media. Yogyakarta: LKiS Pelangi Aksara., 2002 